\title{
Value of the indirect immunofluorescence test in the diagnosis of vaginal candidiasis
}

\author{
D. W. WARNOCK AND A. L. HILTON \\ From the Departments of Microbiology and Venereology, Bristol Royal Infirmary
}

\section{Summary}

An indirect immunofluorescence test was used to determine the titre of serum antibodies to Candida albicans in 300 female patients. Titres from $1: 4$ to $1: 16$ were detected in 85 uninfected subjects and nineteen subjects with gonococcal infection. Titres from $1: 4$ to $1: 16$ were also detected in 166 of 169 patients found to be harbouring $C$. albicans, $C$. parapsilosis, or $C$. tropicalis in the digestive tract, genital tract, or both, without overt clinical infection. Titres from 1:32 to $1: 128$ were detected in one of four patients with vaginal candidiasis as compared with eleven of 23 patients with vaginal candidiasis who were also harbouring $C$. albicans or $C$. parapsilosis in the digestive tract. It is emphasized that titres of less than 1:32 did not preclude vaginal candidiasis.

\section{Introduction}

The varied clinical spectrum of vaginal infection with Candida albicans has led to an increasing interest in the use of serological tests as an adjunct to the diagnosis of vaginal candidiasis (Stanley, Hurley, and Carroll, 1972; Stanley and Hurley, 1974).

It has been reported that the indirect immunofluorescence test is helpful in the diagnosis of some forms of superficial candidal infection. Using this test, it has been possible to differentiate patients with oral candidiasis from uninfected persons and from persons harbouring Candida albicans in the mouth (Lehner, 1966).

During an investigation into the relationship between the presence of Candida albicans in the female genital and digestive tracts, the chance arose to determine the value of the indirect immunofluorescence test in the diagnosis of vaginal infection with C. albicans.

Received for publication August 8, 1975

Address for reprints: D. W. Warnock, B.SC., Ph.D., Department of Microbiology, Bristol Royal Infirmary, Bristol BS2 8HW

\section{Methods}

\section{Subjects}

Altogether 300 non-pregnant female patients aged between 16 and 45 years who were attending the Department of Venereology were included in this investigation. The methods used in the clinical and microbiological investigation of these patients have been described elsewhere (Hilton and Warnock, 1975).

$5 \mathrm{ml}$. blood were taken from each patient and the serum separated and stored at $-20^{\circ} \mathrm{C}$. until required.

\section{Preparation of antigen}

One strain of Candida albicans belonging to group A (London School of Hygiene and Tropical Medicine 3153), maintained on glucose peptone medium, was used throughout this investigation. A cell suspension was prepared using 0.4 per cent. formal saline to harvest the cells; the suspension was diluted to 12,000 cells per $\mathrm{ml}$. and stored at $4^{\circ} \mathrm{C}$. for no longer than $3 \mathrm{mths}$. One drop of this antigen suspension was placed on each glass slide, dried at room temperature, and then flamed.

\section{Immunofluorescence test}

The clinical status pertaining to each serum specimen was not known when the immunofluorescence test was performed.

Doubling dilutions of serum from 1:4 were made with phosphate buffered saline (PBS) $\mathrm{pH} 7 \cdot 1$. One dilution of serum was placed on each antigen preparation. These were incubated for $30 \mathrm{~min}$. at $37^{\circ} \mathrm{C}$. in a moist chamber before being rinsed in two changes of PBS for $5 \mathrm{~min}$. each. Fluorescent antihuman globulin (Wellcome) was placed on each preparation and left for $30 \mathrm{~min}$ at $37^{\circ} \mathrm{C}$. Each preparation was again rinsed in two changes of PBS for $5 \mathrm{~min}$. each and then mounted in buffered glycerol for examination. Negative and positive control preparations were included on each occasion.

The essential criterion of positive immunofluorescence was taken to be a complete ring of bright green fluorescence around the cells. Tests with untreated Candida albicans cells and with cells treated with fluorescent antihuman globulin alone did not give this distinctive fluorescence. The highest dilution of serum giving a complete ring of bright green fluorescence around the cells was taken as the titre of the serum. Observation of the gradual fading of the fluorescence with increasing 
dilution of the serum helped in determining the end-point and, in cases of doubt, the test was repeated. The statistical validity of the results was assessed by the $\chi^{2}$ test.

\section{Results}

Table I summarizes the principal mycological findings for the 300 patients seen during this investigation.

TABLE I Principal mycological findings in the 300 patients

\begin{tabular}{|c|c|c|c|}
\hline \multirow[t]{2}{*}{$\begin{array}{l}\text { Site }(s) \text { of } \\
\text { infection }\end{array}$} & \multicolumn{2}{|c|}{$\begin{array}{l}\text { No. (and } \\
\text { proportion) of } \\
\text { patients }\end{array}$} & \multirow[t]{2}{*}{ Species isolated } \\
\hline & No. & Per cent. & \\
\hline Genital tract & $16^{\mathrm{a}}$ & $5 \cdot 3$ & $\begin{array}{l}15 C \text {. albicans }+1 C . \\
\text { parapsilosis }\end{array}$ \\
\hline $\begin{array}{l}\text { Genital tract }+ \\
\text { Digestive tract }\end{array}$ & $68^{b}$ & $22 \cdot 7$ & $\begin{array}{l}67 \text { C. albicans }+1 C . \\
\text { parapsilosis }\end{array}$ \\
\hline Digestive tract & 112 & $37 \cdot 3$ & $\begin{array}{l}10 \text { C. albicans }+3 \text { C. } \\
\text { parapsilosis }+2 \text { C. tropicalis }\end{array}$ \\
\hline No yeast infection & 104 & $34 \cdot 7$ & \\
\hline
\end{tabular}

$\$ 4$ patients with clinical vulvovaginitis

b23 patients with clinical vulvovahginitis

On the basis of these findings, the patients were classified into four groups:

(1) 85 subjects who were free from signs of vulvovaginitis and were not harbouring yeasts in the digestive tract or genital tract.

(2) 19 subjects with gonococcal infection; none of these patients was harbouring yeasts in the digestive or genital tract.

(3) 169 subjects who were free from signs of vulvovaginitis but were harbouring yeasts in the digestive tract, genital tract, or both; 26 of these patients had concomitant gonococcal infection.

(4) 27 subjects with clinical vulvovaginitis; these patients were considered to have vaginal candidiasis since pruritus and discharge were accompanied by isolation of the fungus from the genital tract; three of these subjects had concomitant gonococcal infection.

Table II gives the titres of antibodies to Candida albicans in the 85 uninfected subjects and the nineteen subjects with gonococcal infection alone. Most of these persons had titres up to $1: 8$ and none had titres greater than 1:16.

TABLE II Titre of antibodies to Candida albicans in serum from uninfected subjects and patients with gonococcal infection

\begin{tabular}{|c|c|c|c|c|c|}
\hline \multirow[b]{2}{*}{ Diagnosis } & \multirow{2}{*}{$\begin{array}{l}\text { No. of } \\
\text { patients }\end{array}$} & \multicolumn{4}{|c|}{ No. of persons with a titre of: } \\
\hline & & $1: 4$ & $1: 8$ & $1: 16$ & $1: 32$ \\
\hline \multirow{2}{*}{$\begin{array}{l}\text { No infection } \\
\text { Gonococcal } \\
\text { infection }\end{array}$} & 85 & 55 & 26 & 4 & 0 \\
\hline & 19 & 14 & 5 & 0 & 0 \\
\hline
\end{tabular}

Table III summarizes the titres of antibodies in the 169 subjects harbouring yeasts in the digestive tract, genital tract, or both. The titres in these persons ranged from $1: 4$ to $1: 32$ although 166 of them had titres up to $1: 16$. Titres of $1: 32$ or higher were therefore considered to be significant.

TABLE III Titre of antibodies to Candida albicans in serum from subjects harbouring yeasts in the genital tract, digestive tract, or both

\begin{tabular}{|c|c|c|c|c|c|c|}
\hline \multirow{2}{*}{$\begin{array}{l}\text { Site }(s) \text { of } \\
\text { infection }\end{array}$} & \multicolumn{6}{|c|}{ No. of persons with a titre of: } \\
\hline & $1: 4$ & $1: 8$ & $1: 16$ & $1: 32$ & $1: 64$ & $1: 128$ \\
\hline Genital tract & $5(1)^{a}$ & 3 & 3 & 0 & 0 & 0 \\
\hline $\begin{array}{l}\text { Digestive } \\
\text { tract }\end{array}$ & $45(6)$ & $36(3)$ & $30(2)$ & 1 & 0 & 0 \\
\hline $\begin{array}{l}\text { Genital tract } \\
\text { Digestive } \\
\text { tract }\end{array}$ & $20(8)$ & $13(3)$ & $11(3)$ & 2 & 0 & 0 \\
\hline
\end{tabular}

a Figures in parentheses indicate number of person with concomitant gonococcal infection

Table IV gives the titres of antibodies to Candida albicans found in the 27 subjects with vaginal candidiasis. A titre of more than 1:16 was detected in twelve of these patients; it is interesting that titres of 1:32 or more were detected in 25 per cent. of the patients with genital tract infection as compared with 48 per cent. of those with yeasts present in the digestive as well as the genital tract.

TABLE IV Titre of antibodies to Candida albicans in serum from patients with vaginal candidiasis

\begin{tabular}{|c|c|c|c|c|c|c|}
\hline \multirow{2}{*}{$\begin{array}{l}\text { Site(s) of } \\
\text { infection }\end{array}$} & \multicolumn{6}{|c|}{ No. of persons with a titre of: } \\
\hline & $1: 4$ & $1: 8$ & $1: 16$ & $1: 32$ & $1: 64$ & $1: 128$ \\
\hline Genital tract & 1 & 0 & $2\left(1^{\mathrm{a}}\right)$ & $1(1)$ & 0 & $\mathbf{0}$ \\
\hline $\begin{array}{l}\text { Genital tract + } \\
\text { Digestive } \\
\text { tract }\end{array}$ & 7 & 0 & 5 & $4(1)$ & 5 & 2 \\
\hline
\end{tabular}

aFigures in parentheses indicate number of persons with concomitant gonococcal infection

There was a highly significant difference $\left(\chi^{2}{ }_{1} 281.75 ; P<0.001\right)$ at titres greater than $1: 16$ between patients with vaginal candidiasis and the other groups of subjects. It appears that a titre of 1:32 or higher differentiates patients with clinical signs of infection from other subjects although titres of less than 1:32 do not preclude vaginal candidiasis.

\section{Discussion}

This investigation demonstrates that the indirect immunofluorescence test does not provide a specific test for detecting vaginal infection with Candida albicans. Using this test, it was not possible to separate 
patients who were harbouring $C$. albicans, $C$. parapsilosis, or C. tropicalis in the digestive or genital tract from patients who were not. Nor was it possible to separate these subjects from the patients with vaginal candidiasis. Although titres of 1:32 or more did appear to confirm clinical infection of the genital tract, high titres were more often detected in persons harbouring $C$. albicans or $C$. parapsilosis in the digestive tract in addition to the genital tract.

Our findings further demonstrate that serum from patients with gonococcal infection who were not harbouring Candida albicans in the digestive or genital tract gave similar fluorescence titres to those detected in uninfected persons and patients harbour- ing $C$. albicans without clinical infection. This could perhaps be the result of past candidal infection.

These observations lead us to conclude that the indirect immunofluorescence test is not a useful adjunct to the diagnosis of vaginal candidiasis.

\section{References}

Hilton, A. L., and WarNock, D. W. (1975) Brit. f. Obstet. Gynaec., 82, 922

LeHNeR, T. (1966) F. Path. Bact., 91, 97

Stanley, V. C., and Hurley, R. (1974) f. clin. Path., 27, 66

,-- , and Carroll, C. J. (1972) F. med. Microbiol., 